\title{
The Bingah Scale: A Development of the Happiness Measurement Scale in the Sundanese
}

\author{
Tasya Augustiya ${ }^{1 *}$, Ayu Lestari ${ }^{2}$, Heru Budiman $^{3}$, Raissa Maharani $^{4}$, Mita Anggraini $^{5}$ \\ 1,2,3,4,5 Fakultas Psikologi, Universitas Islam Negeri Sunan Gunung Djati Bandung, Indonesia \\ e-mail:* tasyaaugustiyaxia1@gmail.com
}

\begin{tabular}{|c|c|}
\hline Abstract / Abstrak & Keywords / Kata kunci \\
\hline $\begin{array}{l}\text { This study was conducted to create an instrument that measures the conditions of } \\
\text { happiness felt by the Sundanese in Indonesia. This scale is named the Bingah } \\
\text { Scale. The measurement instrument modification approach was used in this study, } \\
\text { where the researcher had chosen the theoretical construct that was relevant to the } \\
\text { happiness construct in the Sundanese, then made new items that measured the } \\
\text { construct. This modification was carried out to get a more comprehensive } \\
\text { measuring instrument because it was adjusted to the language and culture where } \\
\text { the measuring instrument was used. The number of respondents involved in the } \\
\text { study amounted to } 526 \text { participants who were the representations of the } \\
\text { Sundanese who were selected using a purposive sampling technique. The results } \\
\text { showed that there were } 21 \text { items, both psychometrically and feasible to be used as } \\
\text { appropriate instruments to measure the condition of happiness in Sundanese. }\end{array}$ & $\begin{array}{l}\text { Happiness; } \\
\text { Psychometric } \\
\text { properties; } \\
\text { Scale development; } \\
\text { Sundanese; } \\
\text { The Bingah Scale }\end{array}$ \\
\hline $\begin{array}{l}\text { Studi ini dilakukan untuk menciptakan sebuah instrumen yang mengukur kondisi } \\
\text { kebahagiaan yang dirasakan oleh suku Sunda di Indonesia. Skala ini dinamai the } \\
\text { Bingah Scale. Pendekatan modifikasi alat ukur digunakan dalam penelitian ini, } \\
\text { dimana peneliti telah lebih dahulu memilih konstruk teoretis yang relevan dengan } \\
\text { konstruk kebahagiaan pada suku Sunda, kemudian membuat item-item baru yang } \\
\text { mengukur konstruk tersebut. Modifikasi ini dilakukan dengan tujuan untuk } \\
\text { mendapatkan alat ukur yang lebih komprehensif, karena disesuaikan dengan } \\
\text { bahasa dan budaya dimana alat ukur tersebut digunakan. Responden yang terlibat } \\
\text { dalam penelitian berjumlah } 526 \text { partisipan yang merupakan respresentasi dari } \\
\text { suku Sunda yang dipilih dengan menggunakan teknik purposive sampling. Hasil } \\
\text { penelitian menunjukkan bahwa terdapat } 21 \text { item baik secara psikometris dan layak } \\
\text { digunakan sebagai instrumen yang tepat untuk mengukur kondisi kebahagiaan } \\
\text { pada orang Sunda. }\end{array}$ & $\begin{array}{l}\text { Kebahagiaan; } \\
\text { Properti psikometri; } \\
\text { Pengembangan skala; } \\
\text { Orang Sunda; } \\
\text { The Bingah Scale }\end{array}$ \\
\hline
\end{tabular}

\section{Pendahuluan}

Kebahagiaan merupakan awal dari kesejahteraan di dunia. Hal itu dicetuskan oleh Perserikatan Bangsa-Bangsa (PBB) dalam konferensinya pada 28 Juni 2012 dengan Resolusi menjadikan kebahagiaan sebagai tujuan asasi manusia. Pada Resolusi itu pula PBB menetapkan 20 Maret sebagai Hari Kebahagiaan Internasional yang diperingati dengan adanya pengukuran kebahagiaan pada 193 negara anggota PBB. Hal tersebut dimaksudkan juga untuk menunjukkan bahwa kebahagiaan merupakan sesuatu yang dapat diukur (Helliwell dkk., 2018). Resolusi PBB tersebut mendukung perkembangan Psikologi Positif yang sedang menekankan banyak penelitian dalam ranah positif agar rumpun psikologi tersebut semakin berkembang pesat, terutama setelah era-era sebelumnya bidang keilmuan psikologi hanya berfokus kepada ketidakbahagiaan dan penderitaan manusia dibandingkan optimalisasi fungsi-fungsi positif individu (Jahoda, 1985 dalam Ryff, 1989). Psikologi Positif adalah sebuah studi tentang fungsi manusia dalam hal positif dan berkembang pada beberapa aspek seperti biologi, personal, relasional, kelembagaan, budaya, dan dimensi global hidup (Seligman \& Csikszentmihalyi, 2014).

Perserikatan Bangsa-Bangsa (PBB) melalui Lembaga Jaringan Solusi Pembangunan Berkelanjutan, mengumumkan Finlandia 
sebagai negara paling bahagia di dunia dalam 2 tahun berturut-turut, pada Rabu 20 Maret 2018. Rilis daftar yang bertepatan dengan Hari Kebahagiaan Internasional tersebut dirilis berdasarkan pada Laporan Kebahagiaan Dunia 2018 yang mengukur 'kesejahteraan subjektif', yaitu seberapa bahagia seseorang merasakannya dan alasannya. Sementara pada hasil tersebut, Indonesia berada di peringkat 96 dari 156 negara, persis berada di bawah sesama negara Asia Tenggara, yaitu Vietnam, dan di atas beberapa negara ASEAN lainnya, seperti Laos dan Myanmar (Helliwell dkk., 2018). Berdasarkan Indeks Kebahagiaan yang dirilis oleh Badan Pusat Statistik (BPS), menyatakan bahwa Maluku Utara merupakan provinsi paling bahagia di Indonesia. Provinsi tersebut memiliki Indeks Kebahagiaan dengan angka 75.68 dimana suku Abui merupakan suku yang paling bahagia di Indonesia. Alasan yang membuat Maluku Utara menjadi provinsi yang paling bahagia adalah mereka memiliki kepuasan hidup yang baik dan juga sosial yang baik (BPS, 2017). Hal tersebut sesuai dengan definisi kebahagiaan yang dikemukakan oleh Argyle dan Hills (2002) bahwa kebahagiaan merupakan suatu hal dimana seseorang sering merasakan emosi positif berupa kegembiraan serta merasa puas terhadap diri dan kehidupannya. Selain itu, Argyle dan Hills (2002) serta Hills dan Argyle (2001) juga mendefinisikan kebahagiaan sebagai kesejahteraan atau kebahagiaan psikologis, dimana konstruksi multidimensinya terdiri dari unsur-unsur emosional dan kognitif dalam hal pengaruh positif dan negatif yang terpisah, serta merupakan gabungan dari perasaan, suasana hati dan respon emosional individu terhadap berbagai kesenangan dan kepuasan.

Sementara itu, terdapat 8 provinsi yang berada di bawah Indeks Kebahagiaan Indonesia, yakni Bengkulu, Jambi, Kalimantan Barat, Sulawesi Barat, Banten, Jawa Barat, Lampung, Nusa Tenggara Timur, dan Papua (BPS, 2017). Dari data tersebut dapat diketahui bahwa Jawa Barat berada pada urutan 29 dari 34 Provinsi dalam indeks kebahagiaan di Indonesia, dimana permasalahan tersebut sesuai dengan hasil penelitian sebelumnya yang dilakukan oleh Saraswati (2014) mengenai perbandingan kebahagiaan pada beberapa Suku di Indonesia, pada penelitian tersebut didapatkan bahwa kebahagiaan orang dengan latar belakang suku Sunda memiliki skor terendah yang berarti paling tidak bahagia dibandingkan dengan suku lainnya, diantara hasilnya adalah Minang (174.40), Batak (173.76), Jawa (173.40), dan Sunda (172.89).

Fakta ilmiah yang menyatakan bahwa suku Sunda tidak bahagia disebabkan adanya kesenjangan ekonomi antara kelompok dengan perekonomian tinggi dan yang rendah (Jaenudin \& Tahrir, 2019). Sejumlah inovasi yang telah dilakukan untuk meningkatkan indeks kebahagiaan di Jawa Barat telah dilakukan, seperti peningkatan ruang publik atau tamantaman, interaksi melalui media sosial, menemui warga tidak mampu, hingga program Kekasih Juara. Ketidakbahagiaan orang Sunda yang ditunjukkan oleh data BPS dan penelitian sebelumnya tidak selaras dengan nilai-nilai yang ada pada kehidupan orang Sunda. Dalam perkembangannya, budaya Sunda terdiri atas sistem kepercayaan, mata pencaharian, kesenian, kekerabatan, bahasa, ilmu pengetahuan dan teknologi, serta adat istiadat (Fathurroja dkk., 2018; Perceka dkk., 2019; Rahman dkk., 2018). Sistem-sistem tersebut melahirkan nilai-nilai yang dianut oleh masyarakat Sunda secara turun-temurun. Budaya Sunda memiliki nilai-nilai yang dijunjung tinggi oleh masyarakat Sunda yang tercermin dalam pameo silih asih (saling mengasihi), silih asah (saling memperbaiki diri), dan silih asuh (saling melindungi). Nilai lainnya yang juga melekat pada budaya Sunda yaitu nilai kesopanan, rendah hati terhadap sesama, kebersamaan, gotong-royong, dan konsep kepuasan hidup sederhana yang tersurat dalam wangsit Prabu Siliwangi sebagai sosok manusia Sunda yang agung dan pinilih dalam merumuskan konsep hidupnya yang selalu cukup dengan apa yang telah didapatkannya (Fitriyani dkk., 2015).

Peneliti melakukan survei awal untuk mengetahui kondisi kebahagiaan suku Sunda 
dimana peneliti melakukan survei terhadap 14 orang yang berasal dari suku Sunda di berbagai daerah. Pada hasil data awal tersebut menunjukkan bahwa masyarakat Sunda bahagia. Ketika diberikan pilihan rentang angka 1-10 untuk menggambarkan kebahagiaan mereka, rata-rata orang tersebut memilih pada angka 8 yang artinya bahagia. Dari data tersebut juga didapatkan bahwa alasan mereka bahagia adalah ketika mereka dapat berkumpul dengan orang yang mereka cintai seperti keluarga, teman, dan sebagainya. Sementara 6 responden lainnya mengatakan bahwa alasan mereka bahagia adalah ketika mereka bisa mendapatkan apa yang mereka inginkan, dapat memenuhi kebutuhan dan mendapat nikmat Tuhan, dengan kata lain memiliki kepuasan hidup. Selain itu, ketika ditanya kembali mengenai momen apa yang biasanya membuat mereka bahagia, responden umumnya menjawab bahwa mereka bahagia ketika dapat mencapi target, mendapatkan apa yang diinginkan dan mendapatkan yang dibutuhkan. Dari data tersebut didapatkan bahwa orang Sunda memaknai kebahagiaannya ketika telah mencapai kepuasan hidup.

Melihat fenomena tersebut, nilai budaya dan kebahagiaan menjadi hal yang tidak dapat dipisahkan. Hal ini sejalan dengan yang telah dikemukakan oleh Grinde (2002), kebahagiaan dipengaruhi oleh warisan genetik manusia, termasuk konsep-konsep universalitas lintasbudaya yang menggambarkan keadaan ini. Selain itu, Ryff mengemukakan bahwa faktorfaktor yang melatarbelakangi kebahagiaan seseorang, salah satunya adalah budaya dan akan memberikan perbedaan dalam gambaran kebahagiaan individu (Ryff, 1989). Beberapa ahli budaya mengemukakan bahwa budaya memberikan sebuah kerangka berpikir tertentu melalui internalisasi nilai-nilai kepada anggota budaya tersebut dalam bersikap dan berperilaku, sehingga pada akhirnya kebahagiaan individu dari latar belakang budaya tertentu pun akan dipengaruhi oleh nilai-nilai tersebut (Saraswati, 2014). Sayangnya, penelitian mengenai kebahagiaan dan budaya belum banyak dilakukan di dunia, termasuk di Indonesia.

Di Indonesia, penelitian mengenai kebahagiaan dalam pendekatan budaya telah dilakukan oleh Anggoro dan Widhiarso (2010) dengan menciptakan Skala kebahagiaan Indigenous. Pada skala ini, kebahagiaan didefinisikan sebagai proses pemenuhan rasa atau ikatan keluarga, prestasi atau pencapaian pribadi, relasi sosial yang baik, serta tercukupinya kebutuhan spiritual individu yang didasarkan pada afek positif (Anggoro \& Widhiarso, 2010). Selain itu, Saraswati (2014) melakukan studinya mengenai perbandingan 5 budaya di Indonesia termasuk Sunda menggunakan alat ukur kebahagiaan dari Ryff dimana alat ukur itu terdiri dari 6 aspek yaitu: self acceptance, positive relation with other, autonomy, personal growth, environmental mastery serta purpose of life. Alat ukur tersebut hampir sama dengan skala kebahagiaan yang dibuat oleh Seligman, kebahagiaan dapat dilihat dari emosi positif tentang masa lalu, emosi positif masa kini atau emosi positif tentang masa depan (Seligman, 2002). Studi lainnya dilakukan oleh Marliani dkk. (2019) yang mengeksplorasi 3 alat ukur kebahagiaan yang pararel namun tidak spesifik dilakukan pada suku Sunda. Begitu pula yang dilakukan oleh Muhopilah dkk. (2018) serta Royanulloh dan Komari (2019) yang memfokuskan pengembangan instrumen kebahagiaan dalam konteks agama dan religiusitas semata. Diantara alat ukur-alat ukur sebelumnya mengenai kebahagiaan dalam konteks budaya, tidak ada satupun yang membahas tentang kepuasan hidup dimana dimensi itu merupakan dimensi utama yang sesuai dengan falsafah hidup budaya Sunda dan selaras dengan studi awal mengenai makna bahagia menurut orang Sunda, sehingga penelitian ini bertujuan untuk membuat alat ukur kebahagiaan Sunda yang dinamai sebagai the Bingah Scale.

\section{Metode}

Peneliti menggunakan metode kuantitatif, dimana data yang tersaji berisi angka-angka dan 
hasil pengolahan datanya menggunakan program-program statistika (Baumert dkk., 2017; Fleeson \& Jayawickreme, 2014). Pengembangan alat ukur kebahagiaan yang dilakukan mengikuti langkah Hinkin dkk. (1997) yang dalam proses modifikasi alat ukur diperlukan 7 tahapan. Tahapan pertama yaitu membuat item berdasarkan teori, dimana alat ukur yang dikembangkan oleh peneliti mengikuti teori yang dikemukakan oleh Argyle dan Hills (2002), dimana kebahagiaan diartikan sebagai suatu emosi positif yang dirasakan seseorang seperti rasa gembira dan kepuasan diri dalam kehidupannya. Argyle dan Hills (2002), dalam teori kebahagiaannya menyebutkan terdapat tujuh hal yang membuat seseorang bahagia, yakni merasakan kepuasaan hidup, sikap ramah, memiliki pola pikir yang positif, bersikap ceria, harga diri positif, empati dan kesejahteraan. Berdasarkan kesepakatan bersama peneliti, penelitian ini akan menggunakan lima dimensi dari tujuh dimensi kebahagiaan Argyle dan Hills (2002), peneliti membuang dimensi empati dan kesejahteraan dengan alasan kedua dimensi yang dimaksudkan kurang sesuai dengan konstruk kebahagiaan secara teoretis. Lebih jelasnya bisa dilihat pada tabel 1 .

Tabel 1

Rancangan Item Kebahagiaan

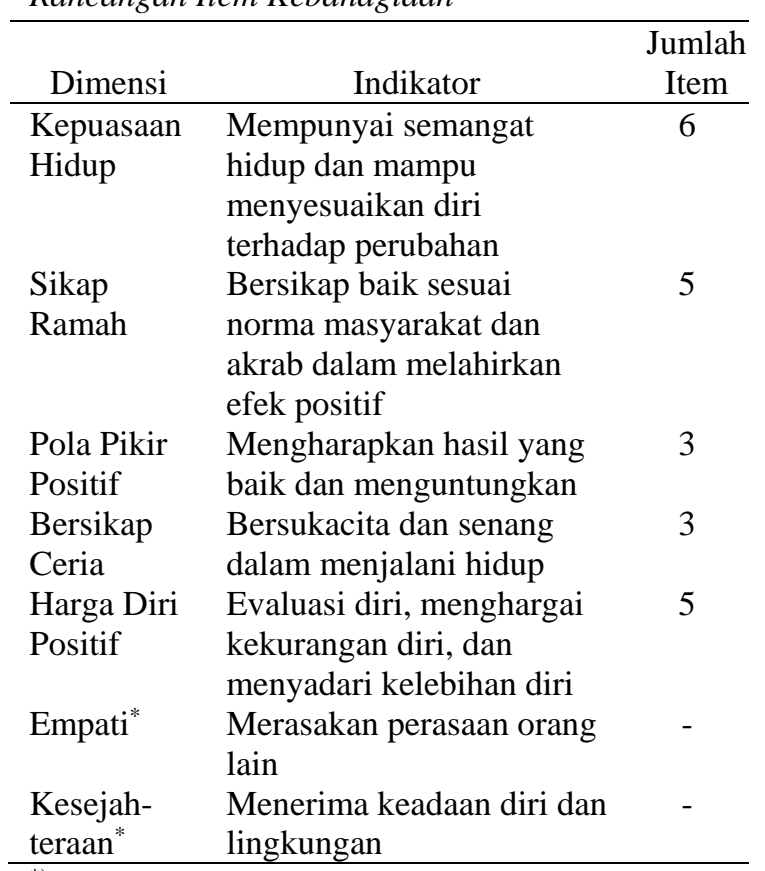

$\left.{ }^{*}\right)$ Dimensi yang dihapus
Tahapan kedua, yaitu menguji validitas konten/ isi dari item-item yang diturunkan dari teori. Menurut Azwar (2017), validitas konten yang dilakukan dengan menggunakan analisis rasional dimana seorang pakar/ ahli melihat apakah tiap-tiap butir soal telah sesuai dengan batasan suatu domain yang telah ditetapkan sebelumnya. Peneliti mengujikan item-item yang dikonstruk kepada 9 ahli dimana para ahli yang biasa disebut rater atau orang yang ahli dan kompeten di bidangnya. Adapun kriteria rater adalah pakar dalam kesundaan, dosen psikologi, pakar statisika dan pakar psikometri (Ramdani, 2018).

Tahapan ketiga adalah pembentukan kuesioner berdasarkan item-item yang telah diuji validitas kontennya. Tahapan keempat adalah melakukan uji analisis faktor, yakni menggunakan Second Order Confirmatory Factor Analysis (Salsabila dkk., 2019). Tahapan kelima adalah menghitung internal consistency menggunakan alpha-cronbach. Tahapan keenam adalah menyesuaikan hasil validitas konten dengan hasil analisis, kemudian tahap terakhir adalah memilih item yang baik yang digunakan dalam penelitian ini agar dapat diaplikasikan untuk penelitian. Alur penelitian yang dilakukan seperti gambar 1 .

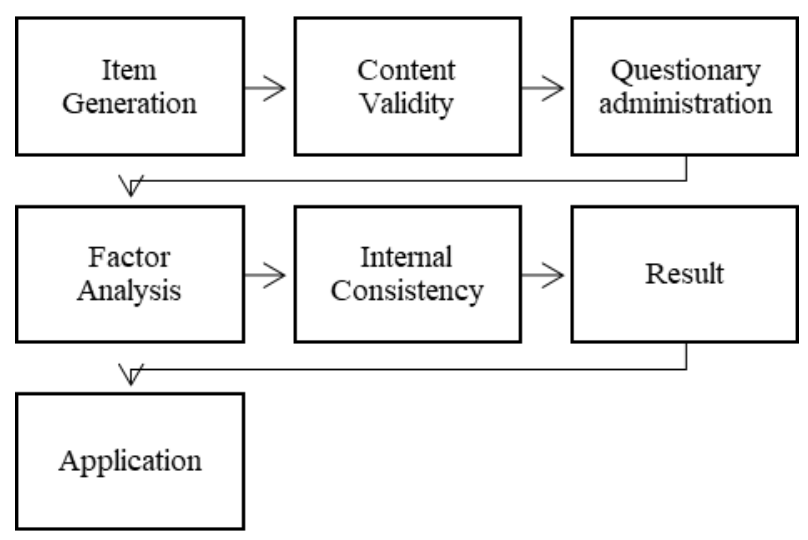

Gambar 1. Langkah-langkah modifikasi alat ukur 
Tabel 2

Hasil Perhitungan Aiken V

\begin{tabular}{|c|c|c|c|}
\hline No & Pernyataan & Aiken V & Hasil \\
\hline \multirow[t]{6}{*}{ D1 } & Saya mampu bangkit kembali ketika gagal & .96 & Valid \\
\hline & Saya mudah menyerah saat mengalami kegagalan & .78 & Valid \\
\hline & Saya dapat menahan emosi ketika gagal melakukan sesuatu & .81 & Valid \\
\hline & Saya mampu berkonsentrasi meskipun sedang sedih & .78 & Valid \\
\hline & Saya selalu emosi ketika gagal melakukan sesuatu & .78 & Valid \\
\hline & Saya mampu beradaptasi dengan lingkungan baru & .78 & Valid \\
\hline \multirow[t]{5}{*}{ D2 } & Saya suka membantu tetangga yang sedang mengalami kesulitan & .78 & Valid \\
\hline & Ketika bertemu teman saya mengabaikannya & .81 & Valid \\
\hline & Saya berteman dengan siapapun & .81 & Valid \\
\hline & Saya suka menasehati teman yang melanggar peraturan & .78 & Valid \\
\hline & Saya membiarkan jika ada teman saya yang melanggar peraturan & .78 & Valid \\
\hline \multirow[t]{3}{*}{ D3 } & Saya berharap kehidupan saya akan sejahtera & .78 & Valid \\
\hline & $\begin{array}{l}\text { Saya yakin akan mendapat hasil yang baik setelah berusaha dengan } \\
\text { maksimal }\end{array}$ & .81 & Valid \\
\hline & Saya percaya akan menjadi orang yang sukses di masa depan & .83 & Valid \\
\hline \multirow[t]{3}{*}{ D4 } & Saya menjalani hari-hari saya dengan riang gembira & .78 & Valid \\
\hline & Saya senang ketika ada teman berkunjung ke tempat tinggal saya & .89 & Valid \\
\hline & Saya merasa hidup saya sangat beruntung & .81 & Valid \\
\hline \multirow[t]{5}{*}{ D5 } & Saya menyadari potensi yang saya miliki & .78 & Valid \\
\hline & Saya mengabaikan kesalahan-kesalahan yang pernah saya perbuat & .85 & Valid \\
\hline & $\begin{array}{l}\text { Saya menyempatkan diri untuk merenungi kesalahan-kesalahan yang } \\
\text { saya perbuat }\end{array}$ & .78 & Valid \\
\hline & Saya mampu memaksimalkan potensi yang saya punya & .78 & Valid \\
\hline & Saya selalu meminta maaf jika berbuat salah pada orang lain & .81 & Valid \\
\hline
\end{tabular}

Note: D adalah Dimensi

Pemilihan partisipan dalam penelitian ini menggunakan teknik purposive sampling. Teknik ini digunakan peneliti karena peneliti mengharapkan adanya kecocokan kriteria partisipan dengan tujuan penelitian. Adapun kriteria partisipan yang peneliti maksudkan adalah partisipan bersuku Sunda dari berbagai kalangan dan beragam usia. Penganalisisan data menggunakan dua program statistik yaitu SPSS dan Lisrel.

\section{Hasil}

Proses pengambilan data penelitian menggunakan dua cara yaitu kuesioner online melalui google form dan kuesioner (paper based) yang disebarkan langsung kepada partisipan. Partisipan penelitian ini terdiri dari 526 partisipan berusia antara 17 tahun sampai dengan 60 tahun. Partisipan berjenis kelamin laki-laki sebanyak 155 orang (29.5\%) dan perempuan sebanyak 371 orang (70.5\%). Pekerjaan partisipan dalam penelitian ini antara lain mahasiswa/ pelajar, guru/ dosen, wiraswasta, buruh, pegawai BUMN, dan ibu rumah tangga.

\section{Uji Validitas Konten}

Aiken merumuskan rumus Aiken $\mathrm{V}$ untuk menghitung koefisien validitas konten. 
Perhitungan tersebut menggunakan rumus Aiken $(\mathrm{V}=\Sigma \mathrm{S} /(\mathrm{n}(\mathrm{c}-1))$, batasan koefisien validitas Aiken dengan penilai sembilan rater sebesar .78 dengan p-value (.05) (Aiken, 1985). Dapat dilihat pada tabel 2 hasil perhitungan validitas konten terhadap 22 item oleh sembilan rater.

Dari perhitungan validitas Aiken yang dilakukan, dapat disimpulkan bahwa seluruh item yang diujikan valid. Setelah diujikan oleh perhitungan rater, analisis selanjutnya yang akan dibahas adalah analisis faktor konfirmatori untuk membuktikan bahwa item-item yang diujikan sesuai dengan teori yang dimaksudkan.

\section{Uji Validitas Konstruk}

Tabel 3

Hasil Uji Validitas Konstruk

\begin{tabular}{ccccc}
\hline Item & $\begin{array}{c}\text { Factor } \\
\text { Loading }\end{array}$ & $\begin{array}{c}\text { Standar } \\
\text { Error }\end{array}$ & T-Value & Ket \\
\hline 1 & .75 & FIXED & FIXED & Valid \\
2 & .43 & .05 & 9 & Valid \\
3 & .58 & .05 & 12.25 & Valid \\
4 & .38 & .05 & 8.12 & Valid \\
5 & .32 & .05 & 7 & Valid \\
6 & .68 & .05 & 12.97 & Valid \\
7 & .66 & FIXED & FIXED & Valid \\
8 & .43 & .05 & 8.83 & Valid \\
9 & .70 & .05 & 13.7 & Valid \\
10 & .43 & .05 & 8.91 & Valid \\
11 & .35 & .05 & 7.24 & Valid \\
12 & .77 & FIXED & FIXED & Valid \\
13 & .83 & .05 & 17.95 & Valid \\
14 & .66 & .04 & 14.65 & Valid \\
15 & .73 & FIXED & FIXED & Valid \\
16 & .58 & .05 & 11.7 & Valid \\
17 & .54 & .05 & 11.04 & Valid \\
18 & .50 & FIXED & FIXED & Valid \\
19 & .64 & .06 & 11.7 & Valid \\
20 & .19 & .04 & 4.4 & Tidak \\
21 & .60 & .06 & 9.97 & Valid \\
22 & .58 & .06 & 9.98 & Valid \\
\hline & & & &
\end{tabular}

Alat ukur penelitian ini dianalisis dengan model second order $\left(\chi_{(167)}^{2}=381.57, \mathrm{p}<.05 \&\right.$ RMSEA < .05) menunjukkan bahwa model yang digunakan fit atau sesuai model pengukurannya. Ditemukan dari 22 item hanya 1 item yang perlu di-drop, yaitu item 20 yang memiliki nilai factor loading kurang dari .3. Hal ini sejalan dengan diskusi penelitian Salsabila dkk. (2019) yang dalam penganalisisannya menggunakan batasan .3 untuk menentukan item yang baik. Apabila dilihat dari model second order yang digunakan, kelima dimensi yang dipilih oleh peneliti adalah dimensi yang benar mengukur happiness. Khususnya penelitian ini memadukan teori happiness dan partisipan dari suku Sunda (disesuaikan dengan budaya Sunda), oleh karenanya peneliti menamakan alat ukur ini BINGAH-Scale.

\section{Uji Reliabilitas BINGAH-Scale}

Hasil uji reliabilitas menggunakan SPSS yang dilakukan pada BINGAH-Scale untuk dimensi kepuasan hidup memiliki nilai $\alpha=$ .751 , dimensi sikap ramah sebesar $\alpha=.753$, dimensi berpikir positif sebesar $\alpha=.839$, dimensi ceria $\alpha=.796$, dan dimensi harga diri positif sebesar $\alpha=.753$. Nilai reliabilitas yang dihasilkan lebih besar dari .7, artinya kelima dimensi yang diukur reliabel, sesuai dengan pendapat Azwar (2017) yang mengatakan batasan alat ukur yang baik saat nilai reliabilitas $>$.7. Untuk memastikan kembali bahwa seluruh item mengukur kebahagiaan, diketahui bahwa reliabilitas seluruh item pada alat ukur BINGAH-Scale adalah $\alpha=.741$, artinya reliabel.

\section{Diskusi}

Pembuatan alat ukur menggunakan pendekatan modifikasi dalam penelitian ini menghasilkan skor yang relevan dengan masing-masing properti psikometri yang diukur. Dengan adanya landasan teoretis yang jelas akan mempermudah peneliti dalam melakukan modifikasi alat ukur yang dibuat. Ketika peneliti akan menyusun alat ukur yang baik, teori yang diperoleh dari sumber utama 
akan sangat baik untuk membantu dalam proses operasionalisasi item (Beaton dkk., 2013). Dalam penelitian ini, peneliti menggunakan teori Argyle dan Hills (2002), mengenai kebahagiaan dimana alat ukur menggunakan 7 dimensi atau aspek untuk mengukur kebahagiaan tersebut. Namun yang digunakan peneliti hanya 5 dimensi.

Penggunaan 5 dimensi dalam penelitian ini didasarkan pada pemahaman bahwa ada dua dimensi yang ketika dilakukan eksplorasi secara teoretis akan mengalami overlap dengan dimensi lainnya, sehingga 2 dimensi tersebut dihilangkan. Overlap item seringkali menghasilkan sebuah item yang berbeda tetapi mereka mengukur hal yang sama, sehingga yang terjadi adalah ketidakonsistenan item dalam mengukur konstruk tersebut. Kedua dimensi tersebut bisa jadi menjadi bagian kecil yang seharusnya bisa dimasukkan ke dalam dimensi lainnya yang lebih representatif. Dua dimensi yang dihilangkan sebagaimana telah dijelaskan sebelumnya oleh peneliti, yaitu dimensi empati dan kesejahteraan adalah dimensi yang tidak cocok dengan perspektif teoretis kebahagiaan. Secara teoretis, kedua dimensi yang dimaksudkan muncul sebagai bagian dari psychological well-being yaitu konstruk kesejahteraan psikologis yang berbeda dengan yang terjadi pada happiness. Happiness sendiri adalah bagian dari subjective well-being yang lebih mengukur kebahagiaan dalam pengertian yang lebih individualis. Kedua dimensi itu mungkin muncul karena pertimbangan sejak awal pada teori Argyle dan Hills (2002), yang dijadikan rujukan sebelumnya. Dengan demikian hanya 5 dimensi yang dipandang sesuai dengan perspektif kebahagiaan dalam penelitian ini.

Dari hasil penganalisisan validitas Aiken diketahui bahwa 22 item yang mengukur 5 dimensi yang dimaksudkan lolos, artinya melewati nilai batas aiken yang harus dipenuhi, yakni .78. Namun ketika dilakukan uji validitas konstruk, ditemukan terdapat 1 item yang bermasalah karena memiliki nilai faktor loading di bawah .3 yaitu item 20. Hal ini menunjukkan bahwa dalam penelitian ini sebanyak apapun rater yang digunakan untuk melakukan uji validitas alat ukur, belum tentu sejalan dengan analisis yang dilakukan dengan menggunakan program statistik. Untuk nilai reliabilitas alat ukur baik per dimensi maupun secara keseluruhan diketahui alat ukur yang dikembangkan selain valid, juga reliabel.

Studi ini menghasilkan properti psikometris yang cukup baik karena dilihat dari berbagai aspek, BINGAH-Scale ini dibuat berdasarkan kematangan dalam menentukan perspektif teoretis sejak awal, yang kemudian akan menentukan kontribusi teoretis tersebut terhadap proses pengujian lainnya. Sebanyak 5 dimensi yang dianalisis dalam studi ini juga sangat mewakili perspektif pengalaman suku Sunda yang secara historis memiliki pondasi untuk menjadi individu yang bahagia. Proses pengambilan data yang juga dilakukan dengan komprehensif karena responden yang terlibat sangat mewakili populasi suku Sunda saat ini. Dengan alat ukur ini sendiri diharapkan dapat memberikan informasi yang valid terhadap gambaran kebahagiaan pada suku Sunda.

\section{Simpulan}

Pada hasil perhitungan yang dilakukan menggunakan analisis klasik maupun item response theory (IRT), item pada skala alat ukur modifikasi BINGAH-Scale (Kebahagiaan Sunda) didapatkan 21 item yang baik dan lolos menjadi item final. Hal ini didapat melalui beberapa tahap, diantaranya uji validitas konten oleh 9 rater, uji validitas konstruk dengan CFA, dan uji reliabilitas. Maka dapat disimpulkan alat ukur BINGAH-Scale merupakan alat ukur yang valid dan reliabel mengukur Happiness yang secara khusus untuk suku Sunda.

\section{Referensi}

Aiken, L. R. (1985). Three coefficients for analyzing the reliability and validity of ratings. Educational and Psychological Measurement, 45(1), 131-142. https://doi.org/10.1177/001316448545101 2

Anggoro, W. J., \& Widhiarso, W. (2010). Konstruksi dan identifikasi properti 
psikometris instrumen pengukuran

kebahagiaan berbasis pendekatan indigenous psychology: Studi multitraitmultimethod. Jurnal Psikologi, 37(2), 176188. https://doi.org/ 10.22146/jpsi.7728

Argyle, M., \& Hills, P. (2002). The oxford happiness questionnaire: A compact scale for the measurement of psychological well-being. Personality and Individual Differences, 33(7), 1073-1082. https://doi.org/10.1016/S01918869(01)00213-6

Azwar, S. (2017). Metode penelitian psikologi (2nd ed.). Pustaka Pelajar.

Baumert, A., Schmitt, M., Perugini, M., Johnson, W., Blum, G., Borkenau, P., ... Wrzus, C. (2017). Integrating personality structure, personality process, and personality development. European Journal of Personality, 528, 503-528. https://doi.org/10.1002/per.2115

Beaton, D. E., Bombardier, C., Guillemin, F., Ferraz, M. B., Borsa, J. C., Wamser, G. H., ... Schoemaker, M. M. (2013). Original report life habits in myotonic dystrophy Type 1. Revista Brasileira de Ortopedia, 10(17), 1-10. https://doi.org/10.1111/cch.12124

BPS. (2017). Indeks kebahagiaan provinsi di Indonesia.

Fathurroja, A., Mumtazah, H., Rosiana, R., Pudoli, S. B. M., \& Fridayanti, F. (2018). Gambaran identitas etnis remaja Suku Jawa dan Sunda. Jurnal Psikologi Islam dan Budaya, 1(2), 107-112. https://doi.org/10.15575/jpib.v1i2.3412

Fitriyani, A., Suryadi, K., \& Syam, S. (2015). Peran keluarga dalam mengembangkan nilai budaya sunda: Studi deskriptif terhadap keluarga sunda di komplek perum riung Bandung. Jurnal Sosietas, 5(2).

Fleeson, W., \& Jayawickreme, E. (2014). Whole trait theory. Journal of Research in Personality, $1-11$. https://doi.org/10.1016/j.jrp.2014.10.009

Grinde, B. (2002). Happiness in the perspective of evolutionary psychology. Journal of Happiness Studies, 3(December), 331-354.

Helliwell, J. F., Huang, H., Wang, S., \& Shiplett, H. (2018). International migration and world happiness. World Happiness Report 2018, 13-44. https://s3.amazonaws.com/happinessreport/2018/WHR_web.pdf

Helliwell, J. F., Layard, R., \& Sachs, J. D.
(2018). World happiness report. World Happiness Report.

Hills, P., \& Argyle, M. (2001). Emotional stability as a major dimension of happiness. Personality and Individual Differences, 31(8), 1357-1364. https://doi.org/10.1016/S01918869(00)00229-4

Hinkin, T. R., Tracey, J. B., \& Enz, C. A. (1997). Scale construction: Developing reliable and valid measurement instruments. Journal of Hospitality \& Tourism Research, 21(1), 100-120. https://doi.org/10.1177/109634809702100 108

Jaenudin, U., \& Tahrir, T. (2019). Studi religiusitas, budaya Sunda, dan perilaku moral pada masyarakat Kabupaten Bandung. Jurnal Psikologi Islam dan Budaya, 2(1), 1-8. https://doi.org/10.15575/jpib.v2i1.3445

Marliani, R., Ramdani, Z., \& Imran, J. M. H. (2019). Validation of happiness scale convergence in santri through Multi-trait Multi-method Analysis. Psikohumaniora: Jurnal Penelitian Psikologi, 4(2), 143-156. https://doi.org/10.21580/pjpp.v4i2.3670

Muhopilah, P., Gamayanti, W., \& Kurniadewi, E. (2018). Hubungan kualitas puasa dan kebahagiaan santri pondok pesantren AlIhsan. Jurnal Psikologi Islam dan Budaya, 1(1), 53-66. https://doi.org/10.15575/jpib.v1i1.2071

Perceka, M. Z., Fahmi, I., \& Kurniadewi, E. (2019). Identitas etnik dan asertivitas mahasiswa suku sunda. Jurnal Psikologi Islam dan Budaya, 2(2), 139-152.

Rahman, A. A., Sarbini, S., Tarsono, T., Fitriah, E. A., \& Mulyana, A. (2018). Studi eksploratif mengenai karakteristik dan faktor pembentuk identitas etnik Sunda. Jurnal Psikologi Islam dan Budaya, 1(1), 1. https://doi.org/10.15575/jpib.v1i1.2072

Ramdani, Z. (2018). Construction of academic integrity scale. International Journal of Research Studies in Psychology, 7(1), 8797. https://doi.org/10.5861/ijrsp.2018.3003

Royanulloh, R., \& Komari, K. (2019). Bulan ramadan dan kebahagiaan seorang muslim. Jurnal Psikologi Islam dan Budaya, 2(2), 51-62. https://doi.org/10.15575/jpib.v2i2.5587

Ryff, D. C. (1989). Happiness is everything, or is it? Explorations on the meaning of psychological well-being. Journal of 
Personality and Social Psychology, 57(6), 1069-1081.

Salsabila, D. F., Rofifah, R., Natanael, Y., \& Ramdani, Z. (2019). Uji validitas konstruk indonesian-psychological measurement of islamic religiousness (I-PMIR). Jurnal Psikologi Islam dan Budaya, 2(2), 1-10. https://doi.org/10.15575/jpib.v2i2.5494

Saraswati, I. (2014). Gambaran kebahagiaan mahasiswa fakultas psikologi universitas padjajaran dengan latar belakang budaya batak, jawa, minang, dan sunda. Universitas Padjajaran.
Seligman, M. E. P. (2002). Authentic happiness: Using the new positive psychologyto realize your potential for lasting fulfillment. Free Press.

Seligman, M. E., \& Csikszentmihalyi, M. (2014). Positive psychology: An introduction. In Flow and the Foundations of Positive Psychology (pp. 279-298). https://doi.org/10.1007/978-94-017-9088-8 
THE BINGAH SCALE: A DEVELOPMENT OF THE HAPPINESS MEASUREMENT SCALE IN THE SUNDANESE 